\title{
Assessment the level of some heavy metal in vital body fluids and blood parameters in lactating Awassi ewes
}

\author{
A.A. Hassan, R.A. Asem and A.S. Al-Chalabi* \\ Department of Physiology, Biochemistry and Pharmacology, Veterinary Medicine College, University of Mosul, Mosul, Iraq \\ *email: alisaeedchalaby@yahoo.com
}

(Received October 1, 2018; Accepted December 21, 2018)

\begin{abstract}
The aim of the study was to estimate the level of cadmium, zinc and oxidative stress parameters in serum and milk as well as the blood constituents in local at the age of 3-4 years during the spring and summer seasons. Blood and milk samples were collected from 30 ewes ( 15 each season). The blood samples were allocated to into two tubes, for complete blood profile study and for biochemical analysis. Milk was used for biochemical tests. Blood analysis showed a significant difference between some blood values during the two seasons represented by significant increase of total white blood number, haemoglobin concentration and packed cell volume in circulating blood of lactating ewes during summer season compared with spring season. Red blood cells number and mean corpuscular haemoglobin concentration did not change among the two seasons. Both mean corpuscular volume and mean corpuscular haemoglobin value of lactating ewe increased significantly during spring season with respect to the summer season. The serum glutathione level showed a significant elevation during spring season compared with the summer season, while, the level of malonaldehyde and peroxynitrite free radicle remain constant during the study period. There were no significant changes in the level of cadmium in serum and milk of examined ewes, while the serum level of zinc significantly higher during the spring compared to the summer season and milk zinc level remain stable during both seasons. The study concluded variations in haematological, oxidative stress biomarkers, serum and milk concentration of $\mathrm{Zn}$ and $\mathrm{Cd}$ according to lactation season in ewes.
\end{abstract}

Keyword: Zinc, Cadmium, Oxidative stress, Hematological values Available online at http://www.vetmedmosul.com

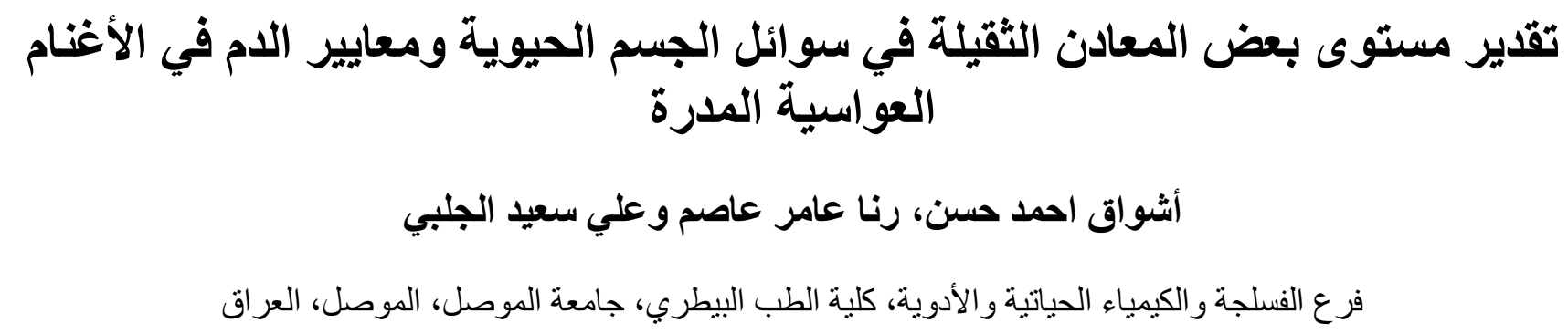

كان الهدف من الدر اسة تقدير مستوى الكادميوم و الزنلك ومعايير الإجهاد التأكسدي في مصل الدم و الحليب بإضافة إلى مكونات الدام في

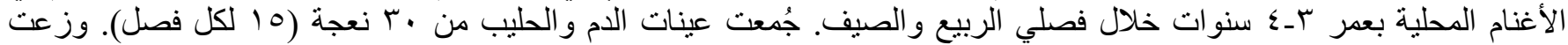

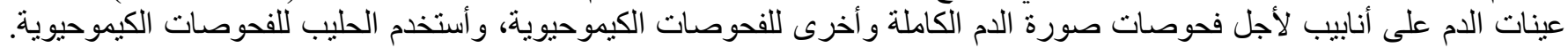

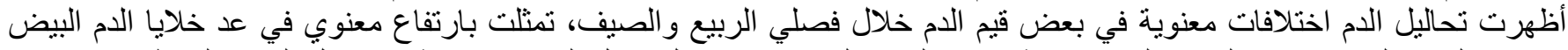

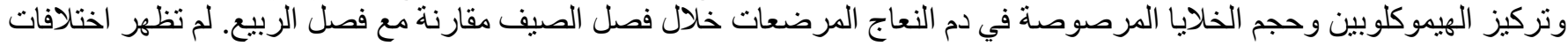

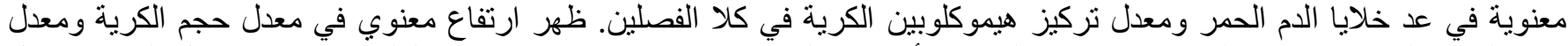

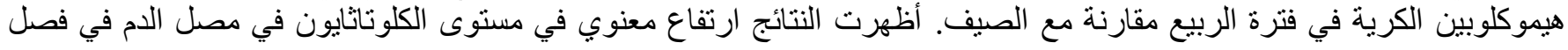




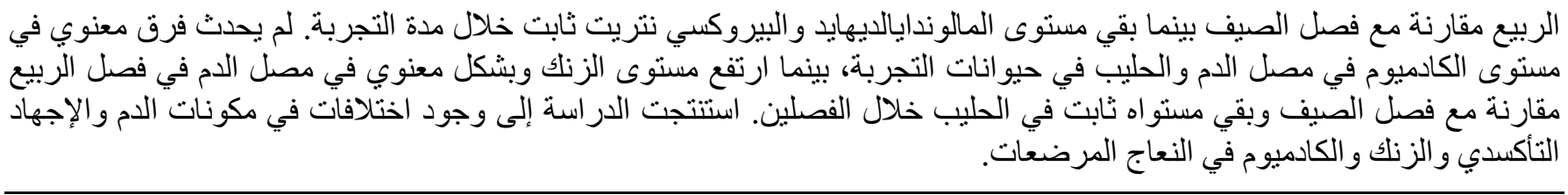

\section{Introduction}

Plenty of sheep herds were being bred in Iraq for the dual purpose (meat and milk production), and Awassi sheep is one of the most favorite one (1). Lactation as physiological condition described by with significant changes in energy resulting from milk production, which in turn is reflected in changes in many metabolic signals (2). The milk is complicated biological substance that plays a vital role in growing lambs and its composition varied according to environmental, nutritional and genetic factors (3). The secretory cells that secreting milk from secretory alveoli during the lactation period use $80 \%$ of the metabolic substances in the blood and its secretion depends on the speed of the filtration of the raw materials from the blood for milk production (4). Milk production is a kind of natural stress, which can happen to the body. Oxidative stress happens due to imbalance between oxidants and antioxidants (5). Reactive oxygen species and hydroxyl radical production due to presence of uncoupled electron that happen naturally in the body as normal metabolic processes (6). The milk contains many antioxidants, for instance, glutathione peroxidase, super oxide dismutase, catalases as well as certain vitamins $\mathrm{C}$ and E. All these antioxidants give protection to suckling lambs against oxidative stress, and these agents are very important in controlling and balancing the reactive oxygen metabolites produced by somatic cells, which presents in the milk (7). The cell damage is protected as results of antioxidant's reaction with reactive oxygen species and glutathione is the best antioxidant produced by cells from amino acids, and malondialdehyde (MDA) is the endpoint of lipid peroxidation in the body, which is the best biomarker for oxidative stress $(8,9)$.

Zinc plays a crucial role in RNA and DNA damage repair system, and interact with various protein productions via enhancement of the metabolic process by protecting proteins' forms from unwanted forms through its regulation to gene expression of certain proteins (10-12). Estrogen and glucocorticoid receptors play a necessary role as good zinc receptors (13).

Cadmium is a heavy toxic metal for the animal body, and the best environmental source is the waste products of industry $(14,15)$. The variation of cadmium milk concentration in farm animals usually fluctuate due to several factors, for instance, suckling period, nutrition status, and lambing season (16). So, the aim of current study is to assess of zinc and cadmium, hematological examination, oxidative stress biomarkers during two different seasons (spring and summer) at Al-Hamdanya district of Mosul city.

\section{Material and methods}

\section{Blood and milk collection}

Thirty adult ewes were employed in this study, randomly distributed in two groups. First group of blood and milk sample was collected during spring season and second group of blood sample were collected during summer (15 sample/ season). All studied ewe were clinically healthy at collection time of blood and milk samples. Blood was allocated into two tubes, one for haematological examination using veterinary Coulter (blood analyzer), and the other part used for serum separation for biochemical analysis. Milk was collected in sterile tubes, kept in a cool box, and transferred to the laboratory for detection of cadmium and zinc using atomic absorption technique.

\section{Biochemical analysis}

Glutathione (GSH) was determined quantitatively using spectrophotometric assay according to (17). Peroxynitrite was determined according to protocol described by (18). Malondialdehyde (MDA) was assessed spectrophotometrically according to (19). Zinc and cadmium detection in milk and serum was done using atomic absorption technique as mentioned by (20).

\section{Statistical analysis}

All the data presented as mean \pm S.E. and statistically assessed at significant value less than 0.05 using SPSS version 23. The difference between groups was evaluated using independent $t$-test (21).

\section{Results}

The data revealed no significant variation in a total number of RBCs count of tested ewe blood sample throughout the study durations, and WBCs count showed significant increase in circulating blood of lactating ewe during summer lactation season. While, $\mathrm{Hb}$ and $\mathrm{PCV}$ values were significantly higher in ewe lactating their lamb during summer than those belonged to spring season at $P$ value less than 0.05 . Both $\mathrm{MCV}$ and $\mathrm{MCH}$ values of lactating 
ewe during spring season increased significantly at $P$ value less than 0.05 with respect to that lactation their lamb during summer (Figure 1).

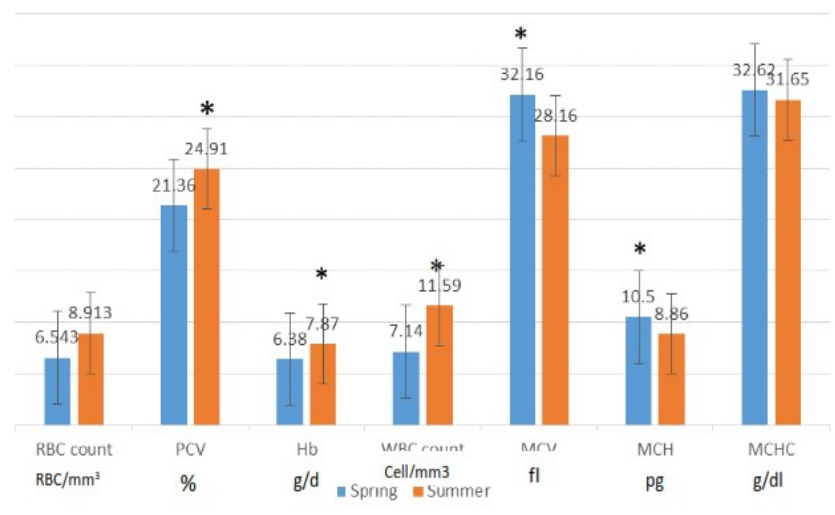

Figure 1: Effect of lactation season variation on haematological values in lactating ewes (Data presented as mean $\pm \mathrm{SE}$, * mean significant variation at $\mathrm{P} \leq 0.05)$.

Glutathione serum level was increased significantly during spring lactating time compare to summer time at $P$ value less than 0.05 . As long as, no significant variation being recorded between spring and summer lactation seasons regarding serum MDA and peroxynitrite radicals' concentrations (Figure 2).

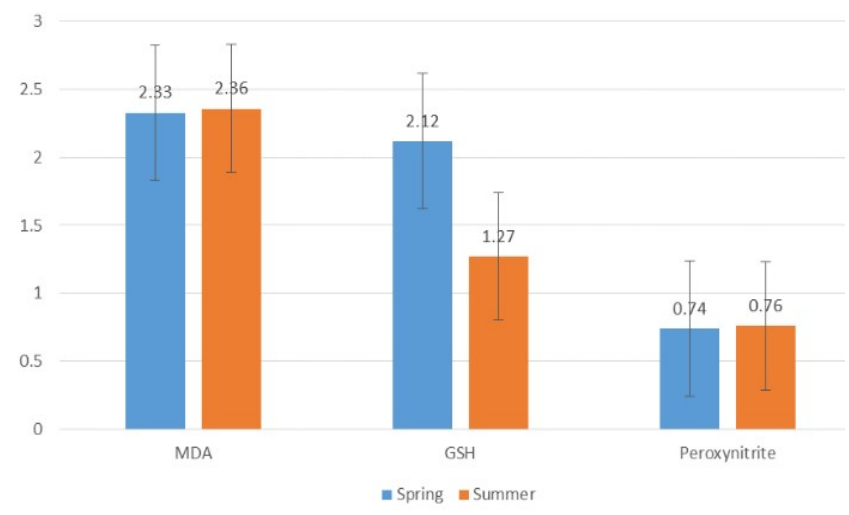

Figure 2: Effect of lactating season on some antioxidants status biomarkers in lactating ewes. Data presented as mean $\pm \mathrm{SE}, *$ mean significant variation at $\mathrm{P} \leq 0.05$.

Serum zinc concentration as $\mathrm{ppm}$ revealed high concentration during a spring lactation season compare to summer lactation season at $P$ value less than 0.05 , although its milk concentration remained constant between both seasons. Both milk and serum cadmium concentrations did not reveal any significant variation between both lactation season's spring and summer of examined ewe (Figure 3).

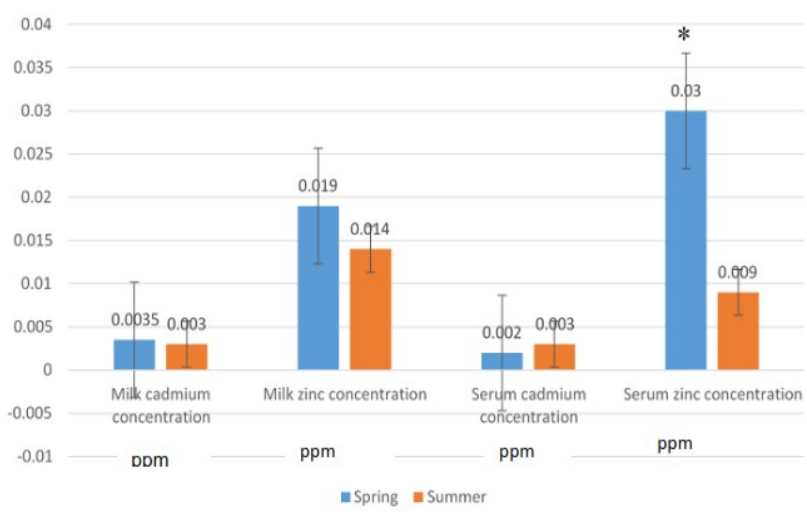

Figure 3: Effect of lactating season on cadmium and zinc concentration in both serum and milk in lactating ewes. Data presented as mean $\pm \mathrm{SE}, *$ mean significant variation at $\mathrm{P} \leq 0.05$.

\section{Discussion}

Data of current study revealed that there is a variation in haematological values in lactating ewe during different seasons. For instance, total WBC count in circulating blood of lactating ewe, during summer was higher than those of spring season, which disagree with Miloslav et al. (22) who, found that total leukocytes were increases in spring. While, agrees with Samarzija et al. (23) who found an increase leukocyte in lactating ewe during a whole lactation season. Another study in 1992 (24), found mild leukopenia in lactating cow starting from day 20 until day 60. Lactating goats showed that there is a decline in total WBC count during lactation was due to migration of neutrophils from blood to milk secreting acini in the mammary gland as a defense mechanism in the udder tissue (25). Another similar study (26) employed lactating goats exhibited increase neutrophils as results of elevation in serum lactase level due to increase production of dehydrogenase during the lactation period, especially in those animals with mild to chronic mastitis (27-29). Total RBCs count exhibited no changes despite of the increase in PCV and $\mathrm{Hb}$ values of summer lactating ewes compare to spring lactating ewes, this results is in similarity to Abdelatif et al. and Tripathi et al. $(30,31)$ who, found that increase PCV, Hb in Awasii ewe during lactation period regardless to the season and may be due to variation influencing factors such as sex, age, breed, nutritional status and grazing in high altitudes areas (32).

Oxidative stress results in the current study, there is a variation in certain biomarkers, for instance, serum glutathione level, which exhibited significant elevation in spring lactating ewe compared to those lactating their lambs in summer. At the same time, MDA plus peroxynitrite radicals did not altered during the study period in both 
lactating seasons. These results does not match the result of Miloslav et al. (33) which exhibited a decline in GSH level in both goats and sheep, while an elevation was recorded in GSH level in lactating buffalo and cow as well as MDA levels without alteration in peroxynitrite level.

Zinc (Zn) plays an essential role in animal nutrition as a component of a number of critical enzymes and is an essential micronutrient required for over 300 different cellular processes, including DNA and protein synthesis, enzyme activity, and intracellular signaling (34). The pancreas, prostate, and mammary gland are secretory tissues that have unusual $\mathrm{Zn}$ requirements and thus must tightly regulate $\mathrm{Zn}$ metabolism through integrating $\mathrm{Zn}$ import, sequestration, and export mechanisms (35). The current study revealed an increase in $\mathrm{Zn}$ serum level during spring lactating season, while, $\mathrm{Zn}$ milk level remained unchanged. This finding does not match the result of Greppi et al. (36) who reported that milk $\mathrm{Zn}$ concentration in spring lower than its concentration in autumn in dairy goats (37) which may be due to difference in nutritional status of dairy goats during lactation season. Variation in serum and milk levels of $\mathrm{Zn}$ depends also on grazing season, breed, and $\mathrm{pH}$ of the soil in grazing areas, which influence on $\mathrm{Zn}$ intake through its concentration in the plants (38). In general, the active secretory tissues utilize $\mathrm{Zn}$ for basic cellular processes but also require $\mathrm{Zn}$ for unique cellular needs, in addition, abundant $\mathrm{Zn}$ is transported into the secretory pathway, and a large amount is subsequently secreted in a tightly regulated manner for unique biological processes $(36,37)$. The role of $\mathrm{Zn}$ in the mammary gland is versatile, because the mammary gland is a dynamic tissue that undergoes dramatic morphological and functional changes; it requires a regulated effort to provide sufficient $\mathrm{Zn}$ for tissue expansion during lactation, which is efficiently ameliorated following weaning (38). In non-lactating animals, the regulation of $\mathrm{Zn}$ metabolism requires the integrated function of number of $\mathrm{Zn}$ transporters to maintain mammary gland $\mathrm{Zn}$ homeostasis for proper cellular function. This is why researchers insist that serum level of metal elements decrease as lactation progress that impact negatively on homeostasis of these elements which play a crucial role as co-enzymes for most physiological processes (39). The average levels of certain elements except sodium in goat and sheep milk is higher than cow milk and their concentration depends on several factors like, nutritional status, health condition and lactation stage (40).

Cadmium (Cd) is an environmental pollutant impact negatively on renal function through its nephrotoxic compounds after chronic exposure (41). Due to the extremely long half-life of cadmium in the animal body, and specifically in the kidney and could be seen in the mammary gland (41). Cd exposure may lead to variations of some hematological values and cause dysfunction in the body physiology, particularly by interfering with calcium and zinc metabolisms (42). The current study revealed that both milk and serum concentrations were not influenced throughout the lactation season, this result is disagreed with Póti et al. (43) who reported that $\mathrm{Cd}$ was higher than acceptable limits in milk of farm animals according to the European Union regulation due to fluctuations of the heavy-metal content were the highest in the grass that leads to increase Cd level in the milk. A previous study in 2006 by Güler (44) found that the Cd low level in milk samples. This may be due to relatively high heavy-metal contents of concentrate and hay. Although the amount of the chromium in milk samples was lower than the values that were reported by Csathó (45).

\section{Conclusion}

The study concludes that there are variations in haematological, oxidative stress biomarkers, $\mathrm{Zn}$, and $\mathrm{Cd}$ data according to lactation season in serum and milk of lactating ewes.

\section{Acknowledgment}

The authors would like to express their gratitude to the owners of sheep herds for their hospitality and their help during samples collection. We Furthermore would express our deep thanks to the laboratory assistants, which gave us their time to analyze the samples.

\section{References}

1. Veerkamp RF, Oldenbroek JK, Van der Gaast HJ, Van der Werf JH. Genetic correlation between days until start of luteal activity and milk yield, energy balance, and live weights. J Dairy Sci. 2000; 83:577-83. https://doi.org/10.3168/jds.S0022-0302(00)74917-4

2. Brogan RS, Michell S, Trayhuran P, Smith MS. Suppression of leptin during lactation: contribution of the suckling stimulus versus milk production. Endocrinol. 1999; 140(6) 2621-2627. https://doi.org/10.1210/endo.140.6.6802

3. Zivkovic J, Sunaric S, Trutic N, Denic M, Kocic C, Jovanovic T. Antioxidants and antioxidant capacity of human milk. Acta Facultatis Medicae Naissensis. 2015; 32(2), 115-125. http://doi.org/10.1515/afmnai-2015-0012

4. Giuseppe B, Erminio T, Rosanna L. Some new aspects of nutrition, health conditions and fertility of intensively reared dairy cows. Italian J Anim Sci. 2009: 8(4), 491-518. https://doi.org/10.4081/ijas.2009.491

5. Agarwal A, Prabakaran SA. Mechanism measurement and prevention of oxidative stress in male reproductive physiology. Indian J Exp Biol. 2005; 43:963-974. PMID: 16315393

6. Wang J, Zhu H, Liu X, Liu Z. Oxidative stress and Ca $\left(2^{+}\right)$signals involved on cadmium-induced apoptosis in rat hepatocyte. Biol Trace Elem Res. 2014; 161(2):180-9. https://doi.org/10.1007/s12011-0140105-6

7. Andrei S, Matei S, Fit N, Cernea C, Ciupe S, Bogdan S, Groza IS. Glutathione peroxidase activity and its relationship with somatic cell count, number of colony forming units and protein content in 
subclinical mastitis cow's milk. Romanian Biotechnol Letters. 2011; 16(3), 6209-6217.

8. Lu SC. Regulation of glutathione synthesis. Molecular aspects of medicine. $\quad 2009 \quad$ Feb $\quad 1 ; \quad 30(1-2): 42-59$. https://doi.org/10.1016/j.mam.2008.05.005

9. Lu SC. Glutathione synthesis. Biochemica et Biophysica Acta.2013; 830(5):3143-3153. https://doi.org/10.1016/j.bbagen.2012.09.008

10. Massanyi P, Nad P, Toman R, Kovacik J. Concentration of cadmium, lead, nickel, copper and zinc in various muscles of sheep. Die Bodenkulter. 2001; 52(3), 255-258.

11. SIMMER, KAREN, and R. P. H. Thompson. "Zinc in the fetus and newborn." Acta Pædiatrica 74 (1985): 158-163. https://doi.org/10.1111/j.1651-2227.1985.tb10126.x

12. Shang $\mathrm{L}, \mathrm{Wu} \mathrm{FY}, \mathrm{Wu} \mathrm{CW}$. Zinc release from xenopus transcription factor III A induced by chemical modifications. Biochem. 1989; 28(25), 9790-9795. https://doi.org/10.1021/bi00451a037

13. Evans RM. The steroid and thyroid hormone receptor superfamily. Sci. 1988; 240(4854):889-895. http://doi,org/10.1126/science.3283939

14. Bampidis AV, Nistor E, Nitas D. Arsenic, Cadmium, Lead, Mercury as undesirable substances in animal feeds. J Anim Sci Biotechnol. 2013; 46(1):17-22.

15. Miller GZ, Harris ZE. Hazardous metals in vintage plastic toys measured by a handheld X-ray fluorescence spectrometer. J Enviro Heal. 2015; 77(6):8-13. https://www.jstor.org/stable/26330178

16. Jelínek P, Gajdušek S, Illek J. Variations of mineral content in sheep milk during lactation. Živoč Výr. 1993; 38:85-96.

17. Rahman I, Kode A, Biswas SK. Assay for quantitative determination of glutathione and glutathione disulfide levels using enzymatic recycling method. Nat Protoc. 2007; 1:3159-3165. http://doi,org/10.1038/nprot.2006.378

18. Mohammed SM, Amin IA, Sabri ZZ. Markers for nitrosative/oxidative stress and SLE 87 nitric oxide, peroxynitrite and malondialdehyde levels as markers for nitrosative/oxidative stress in Iraqi patients with systemic lupus erythematosus. Iraqi J Pharm Sci. 2012; 21(1):87-92.

19. Botsoglou NA, Fletouris DJ, Papageorgiou GE, Vassilopoulos VN, Mantis AJ, Trakatellis AG. Rapid sensitive, and specific thiobarbituric acid method for measuring lipid peroxidation in animal tissue, food, and feedstuff samples. J. Agric. Food Chem. 1994; 42(9), 1931-1937. https://doi.org/10.1021/jf00045a019

20. Ahmed, D.Y Mostaf, H. I Abdella, M R Evaluation of blood lead and cadmium status in sheep grazing on street garbage in Assuit $\begin{array}{llllll}\text { governorate } & \text { IJAVMS } & 2012 ; & 6 & 138 & -142 .\end{array}$ https://doi.org/10.5455/ijavms. 145

21. Steel RGD, Torrie JH. Principle and procedures of statistics. $2^{\text {nd }}$ edition. New York: McGraw-Hill book Company; 1980. 350-386.p.

22. Miloslav S, Pavla V, Jan B, Karel S, Lubos S, Sárka BC, Lubos Z, Simkova A, Katerina S, Skerik V. Relationship between copper and zinc content in the soil and plants and their consequent content in blood and excrements of cattle and sheep under various forms of breeding. Anim Sci Biotechnol. 2013; 46(1), 316-320.

23. Samarzija D, Zamberlin S, Pogacic T. Psychrotrophic bacteria and milk and dairy products quality. Mljekarstvo. 2012; 62(2):77-95.

24. Antiunovic Z, Novoselec J, Sauerwein H, Speranda M, Vegara M, Pavic V. Blld metabolic profile and some of hormones concentration in ewes during different physiological status. Bulgarian J Agri Sci. 2011; 17(5):687-695

25. Paape MJ, Capuco AV, Lefcourt A, Burvenich C, Miller RH. Physiological response of dairy cows to miling in: lpema AH (ed) Proc Int Symp on Prospects for Automatic milking, 1992; 65, 93-105.

26. Das M, Singh M. Variation in blood leucocytes, somatic cell counts, yield and composition of milk crossbred goats. Small Rum Res. 2000; 35:169-174. https://doi.org/10.1016/S0921-4488(99)00088-7
27. Iriadam M. Variation in certain hematological and biochemical parameters during the peri-partum period in kilis does. Small Rum Res. 2007; 73:54-57. https://doi.org/10.1016/j.smallrumres.2006.11.001

28. Kornberg A, Polliack A. Serum lactic dehydrogenase (LDH) levels in acute leukemia: marked elevations in lymphoblastic leukemia. Blood J Hem Lib Org. 1980; 56:351-355. PMID: 6931618

29. Azab ME, Abdal-Maksoud HA. Changes in some haematological and biochemical parameters during pre-partum and post-partum periods in female Baladi goats. Small Rum Res. 34(1), 77-85. https://doi.org/10.1016/S0921-4488(99)00049-8

30. Abdelatif AM, Ibrahim MY, Hassan YY. Seasonal variation in erythrocytic and leukocytic indices and serum proteins of female Nubian goats. Middle East J Sci Res. 2009:4(3):168-174.

31. Tripathi MK, Mishra AS, Mondal D, Misra AK, Prasad R, Jakhmola RC. Caecal fermentation characteristics, blood composition and growth of rabbits on substitution of soya-bean meal by unconventional high-glucosinolate mustard (Brassica juncea) meal as protein supplement. Anim. 2008; 2(2):207-215. https://doi.org/10.1017/S1751731107001152

32. Al-Helaly LA, Rashed SH, Bdaiwi LF. A comparative Study of Oxidant and Antioxidant Levels between Human Milk with Other Types of Ruminant Animals. Iraqi Nat J Chem. 2013:49:86-9.

33. Miloslav S, Pavla S, Jan B, Peter K, Jana S, Mihal U, Bohuslav C. Evaluation of hematological parameters and trace elements in the blood of sheep. Anim Sci Biotechnol. 2010:43(1),.524-527

34. Kelleher SL, McCormick NH, Velasquez V, Lopez V. Zinc in specialized secretory tissues: Roles in the pancreas, prostate, and mammary gland. Adv Nutr. 2011; 2:101-111. https://doi.org/10.3945/an.110.000232

35. Girish BN, Rajesh G, Vaidyanathan K, Balakrishnan V. Zinc status in chronic pancreatitis and its relationship with exocrine and endocrine insufficiency. J Pancreas. 2009; 10(6):651-656. PMID: 19890187

36. Greppi GFA, Ciceri M, Pquini U, Falaschi G, Enne A. Milk yield in dairy goats and blood metabolites. Proc. Of the IDF/CIrVAL Seminar on production and utilization of sheep and goat milk. Crete, Greece, 1995:19-21, 47.

37. Ranjith D, Pandey JK. Mineral profiles in blood and milk of sheep. Inter J Sci Res. 2013; 5(11):2319-7064.

38. Zadak Z. Nutrition in intensive care. Grada Pub Praha. 2002; 165-167.

39. Zamberlin S, Antunac N, Havranek J, Samarzija D. Mineral elements in milk and dairy products. Mljekarstvo. 2012; 62(2):111-125.

40. Vahcic N, Hruskar M, Markovic K, Banovic M, Colic BI. Essential minerals in milk and their dairy intake through milk consumption. Mljekarstve. 2010; 60:77-85.

41. Petersson GK, Oskarsson A. Cadmium in milk and mammary gland in rats and mice. Arch Toxicol. 2000; 73:519-527. https://doi.org/10.1007/s002040050003

42. Houpert P, Mehennaoui S, Enriquez BJ, Kolf-Clauw M, Milhaud G. Transfer of cadmium from feed to ewe food products: Variations in transfer induced by lead and zinc. Environ Sci. 1997; 5:127-138.

43. Póti P, Pajor F, Bodnár Á, Bardos L. Accumulation of some heavy metals (Pd, Cd and $\mathrm{Cr}$ ) in milk of grazing sheep in North-East Hungary. J Microbiol Biotechnol Food Sci. 2012; 2:389-394.

44. Güler M. Levels of 24 minerals in local goat milk, its strained yoghurt and salted yoghurt (tuzlu yogurt). Small Rum Res. 2006; 71:130-137. https://doi.org/10.1016/j.smallrumres.2006.05.011.

45. Csathó P. Heavy metal contamination of environment and agricultural production. A review. (In Hungarian) MTA TAKI Budapest. 1994; 155:1-76. http://doi.org/ 10.1007/s10333-010-0205-7. 